\title{
TRANSNATIONAL PLAYERS IN TOURISM: REGIONAL FEATURES OF FUNCTIONING
}

\author{
Denis S. USHAKOV* \\ Suan Sunandha Rajabhat University, International College, Bangkok, Thailand, e-mail: Denis.us@ssru.ac.th
}

Tatiana B. SAMONOVA

Kyiv University of Tourism, Economics and Law, Department of Hotel and Restaurant Business, Kyiv, Ukraine, e-mail: t-samonova@tanu.pro

Ivan I. HAIOVYI

Kyiv University of Tourism, Economics and Law, Department of Hotel and Restaurant Business, Kyiv, Ukraine, e-mail: ii-haiovyi@politechnika.pro

Iryna M. MINICH

Kyiv University of Tourism, Economics and Law, Department of Theory and Practice of Tourism and Hospitality, Kyiv, Ukraine, e-mail: minich@nuos.pro

Kateryna D. DIDENKO

Kyiv University of Tourism, Economics and Law, Department of Tourism and Hotel and Restaurant Business, Kyiv, Ukraine, e-mail: didenko.kate@tanu.pro

Citation: Ushakov, D.S., Samonova, T.B., Haiovyi, I.I., Minich, I.M., \& Didenko, K.D. (2020). TRANSNATIONAL PLAYERS IN TOURISM: REGIONAL FEATURES OF FUNCTIONING. GeoJournal of Tourism and Geosites, 32(4), 1425-1432. https://doi.org/10.30892/gtg.32434-590

\begin{abstract}
The purpose of our research is to describe the types of transnational corporations in tourism from the standpoint of the exis ting approaches to the typology of corporate models and to outline their advantages. The authors used the methods of logical and statistical analysis and the method of large-scale comparison of the analyzed phenomena. The authors described in detail American, German, and Islamic models of tourism conglomerates; analyzed sources of their global competitiveness. As a result of the study, it has been found the differences between the three models including the equation of technological progress, competitiveness growth, and management system.
\end{abstract}

Key words: corporate management, tourism conglomerates, economic policy, investment and operating, corporation competitiveness

\section{INTRODUCTION}

The emergence of large tourism conglomerates has been explained as attempts to monopolize profitable market segments and to exploit large scale or scope economies, in both cases the unavoidable result of its industrialization. Such a general pattern of integration has been interpreted as a trend in which dominant services producers converge to manage increasingly routinized procedures resulting in a standardized commodity, presumably shaping the boundaries of an emergent industry (Khairiree and Ushakov, 2016).

In contrast, others have described an inherently fragmented system in which differentiated and flexible firms can generate economic rents through their competences at developing product innovations (Comerio and Strozzi, 2019). In that scenario, the ability to develop innovative products by exploiting emerging information-intensive services leads to portraying tourism industrial structures as inherently diverse, fragmented, and changing (Bigné and Decrop, 2018). Alternatively, some predict the advent of mega tourism-related services multinationals operating at the nexus of financial, communication, and information-intensive industries and the demise of the tour operator dominated system (Ushakov, 2006). The presence of such discordant scenarios can be explained by structural diversity and methodological difficulties preventing the establishment and testing of theoretical propositions linking tourism technological environment and industrial structures (Al-Zahawai et al., 2019). In both cases, there is a general malaise with the suitability of conventional industry concepts for the study of tourism industrial organization.

Significant differences in organization of the tourism production process, normative-legal infrastructure of corporate management, development of financial institutions has logically predetermined the coexistence of several types of transnation al tourist conglomerates, and this article will consider the key specific features of these corporate types. The aim of the research is to describe the types of transnational corporations in tourism from the standpoint of the existing approaches to typology of corporate models (American, European and Muslim); to outline advantages, bottlenecks and prospects for each of them. The research object of the article is international tourism as a multifactor socioeconomic phenomenon, which is in cause-effect relations with the world economy in general, both being also under the influence of globalization, transnationalization and liberalization processes.

\section{MATERIALS AND METHODS}

Diversity of economic systems, interregional differentiation by the level of economic institutes' development, different traditions of doing business in the countries worldwide have predetermined the existence of a range of economic-legal models of corporations' functioning and management (Chingarande and Saayman, 2018; Comerio and Strozzi, 2019). Among these models, it was differentiated American, German (European), and Islamic models. The research focuses on determining transnational activities at the global tourism market as an essentially new type of production organization in the field of tourist services. And this new type of services' production is grounded and explained in detail.

The theoretical and methodological basis of the study is the scientific works of researchers in the field of the world economy, the activities of transnational corporations in the tourism business and the peculiarities of its influence on the investment potential of national economies. The information-empirical base of the research is presented by the results of the analysis of a number of monographs, printed and electronic periodicals of scientific publications.

\footnotetext{
${ }^{*}$ Corresponding author
} 
The research was carried out on the basis of the use of tools and methods of institutional and systemic approaches. In the course of the work, the methods of logical and statistical analysis, the method of large-scale comparison and comparison of the analyzed phenomena and processes in economic reality were used. The use of a combination of these methods of scientific knowledge made it possible to ensure the reliability of the results of the analysis and synthesis of the data obtained in the process of research. It also made it possible to formulate a number of author's conclusions, applicable in theory and practice.

\section{RESULTS AND DISCUSSION}

\section{Organizational Strategies in American Tourism Conglomerates}

The American style of management is most economy-oriented, rich in knowledge, experience and all related skills and methods. It is deeply rooted in historic and cultural traditions formed by several cultures simultaneously. There were two core preconditions for the formation of this model - the constant inflow of immigrants to the American continent and the interactive economic policy of expansion. At this, the American nation, on the one hand, was actively influencing the world integration processes, and on the other - it was also the subject of such external influence imposed by numerous other national cultures. American corporate management is essentially based on the individual entrepreneurial initiative. Speaking metaphorically, American business ideology is the happy marriage between individualism and competition. Individualism, in its turn, is the reflection of such a social construct in which everyone is supposed to take care of themselves. Thus, every American manager has this relevant positioning and a certain role within the managerial system. Both depend not only upon professionalism or his/her competences but also on manager's awareness that he/she is part of local business culture, certain business traditions and also personal experience obtained at both local and international markets (Duerden et al., 2018). Once an American corporation sets its tactical goals, it becomes flexible to the very maximum in what concerns distribution and redistribution of all types of resources so that to obtain and increase its income in the shortest term possible. In order to achieve such goals a company would need a rather formalized organizational structure with clear and explicit set of aims and tasks for each of its managers. Under such conditions each of these managers would be strongly encouraged to be initiative, to show entrepreneurial spirit, to develop their leadership skills and to make independent and well-grounded decision in the shortest term.

Managerial activity in American tourism companies is based on the principles of individual responsibility and assessment of individual results. It is also oriented on the achievement of primarily short-term, but very much exact (qualitatively and quantitatively) results. The process of decision-making in American companies also belongs to the individual level, just like the responsibility for this decision-making. The methodology of organizational structures' formation for these tourism conglomerates as well as their managerial process in its full compliance with rules and traditions of the American school of management are also based on the distinct distribution of responsibilities and authority, precise application of detailed job descriptions, formal mechanisms of coordination and control.

Organizational schemes in American conglomerates are built, as a rule, in such a way that certain authority is concentrated on a certain manager who is bearing personal responsibility for this certain type of managerial activity. Internal normative regime in an American company is developed taking into account the fact that shareholder capital of companies is usually distributed among a large number of investors who are mostly isolated from each other and often require trustworthy information for adequate decision-making regarding their investments. Thus, regulatory mechanisms of corporate control have been historically developing in American companies with the aim to provide investors with detailed and trustworthy information, guaranteeing them (ideally) equal access to this sort of information (Lin et al., 2019). Developing under the conditions of free market, American tourism conglomerates soon started to differentiate between the function of ownership and the function of control, this division especially concerns the largest co mpanies at the tourism market. Legal division between these two is highly important from both business and social standpoint since investors who are providing their funds and thus owning an enterprise (or part of it) do not really bear any legal responsibility for the activities carried out by this enterprise. Investors hand over all managerial functions to professional managers who are getting paid for performing these functions. Thus, managers become agents (are providing agent services) (Bandurin, 2019). Control over management in tourism companies still belongs to shareholders who are performing it through the mechanisms that are making company's management transparent. Transparency of management is the key guarantee of shareholders' welfare and priority of their interests' satisfaction. Therefore, the most competent managerial body in the American model of corporate management is the Board of directors, while external side of management rests on the well-developed systems of corporate control and managers' incentives. However, we need to mention here that application of these mechanisms does not lead to full transparency of managers' activity and does not guarantee absolute maximization of investors' profit.

A standard strategy of a typical American tourism or hotel company is oriented mostly on achieving higher profitability and favorable reaction of the related stock market so that to achieve the level of dividend payments acceptable for shareholders. Since such a strategy is oriented mostly on satisfaction of shareholders' interests, it is always more of a short-term nature and thus does not really go well with the strategy of long-term investing. Also, of secondary importance become the issues of product renovation or production process optimization. In the vast majority of cases shareholders are much more interested to make use of their current position at the market. Thus, they often tend to underinvest and be more interested to speculate at stock exchange. For many American companies this strategy turned out to be truly damaging, leading to quick loss of competitive position at both national and international markets. As it was already mentioned above, a typical American tourism company belongs to its shareholders. On the other hand, there is a wide range of reasons (significant dispersion of capital, participation of a larger number of shareholders/investors at the same time, formal role of the Board etc.) due to which many shareholders feel more like outsiders, thus, they are more inclined to behave not as true owners of a company but rather as investors who are assessing quality of managerial decisions from the outside, looking mostly at the level of dividend payments and how well the shares are being traded at stock exchange. In this case, well-developed financial market allows all disappointed shareholders sell their shares in a matter of seconds, thus triggering the indirect mechanisms of corporate control (as mergers, acquisitions, buying out etc.). Presence of constant corporate control as such creates certain pressure on all stakeholders and leads to absolute dominance of short-term preferences.

Interestingly, this dominance of short-term priorities has been widely supported by top management of the absolute majority of TNCs operating in the tourism sector. Moreover, short-term priorities were not only supported but also encouraged since all higher-level managers got their bonuses according to annual performance results. Since none of these managers had guarantees they would stay on their positions for more than a year - there was no reason to sacrifice own annual bonus for any of the future goals (Bandurin, 2019). This means that managers, just like shareholders, were never interested in investing current profits as long-term investments. The paradox here is that under such circumstances the interests of both owners and managers go against the interests of production development. Another specific feature of the American type of tourism TNCs is $100 \%$ merger of sectoral enterprises (those working in tourism) with the related financial institutions (including foreign ones). This feature predetermines, to a larger extent, the core principles of corporate management as well as methods of competitive fight used and behavior at the global markets overall. 
All these features of American tourism conglomerates have also led to popularity of M\&A deals at the American market back in the end of the 1990s. Merger deals became widely spread, inter alia, due to dominance of short-term interests of managers, investors and shareholders, and especially because prices for shares of the companies announcing successful strategic mergers used to spike dramatically. One more feature of American tourism TNCs is professional education of their employees, and what is more importantly - conglomerates are generously investing their funds, time and other resources in this education. If we compare, for example, USA and Japan - in terms of high school education the latter is much more advanced, however, when it comes to university education, the situation is exactly the opposite.

One more specific feature of the American model is unity of standards. American companies somehow managed to spread common standards (lean production, quality control and assessment etc.) all over the world. This standardization is actually quite helpful for tourism companies since it helps cutting costs not limiting the offer of services at the same time. Using standardization methodology, companies - at the very first stage of standardization - reduce the number of internal tasks to the very minimum. In tourism business, more specifically, the following items are the most frequent objects for standardization: the number and the volume of consumables used to service clients (starting from paper use in the offices of tourist agencies and ending with the number of towels in 5-star hotels); services provided by suppliers (in cases when the latter are not directly affiliated to the structure of the same TNC); labor force qualifications; the very process of service provision, step by step (e.g., standard time for response, dress code of employees, stages and order of service provision etc.).

Evaluating the key achievements from the American style of corporate management in the tourism sector specifically, we need to mention several peculiarities which have predetermined the whole process of transnationalization in this sector. First of all, we need to mention the emphasized attention of American management to high dividends' provision for their shareholders. This feature has provoked another one - the growing number of mergers and acquisitions in tourism business, mostly because each of such deals got an instant positive response from the stock market. However, one of the preconditions for growing share prices after a merger deal is that corporation, as the key subject in this deal, is supposed to obtain valuable property, and for quite a long period of time this "valuable property" meant exclusively tangible assets (real estate, transportation means, land, shares of other known companies etc.).

For this very reason American tourism conglomerates were prone to engage in mergers with most of the hotel chains in other parts of the world. This became one of the reasons why today American hotel chains are the largest worldwide. They were going for extensive growth mostly, simply following the classical principles of the American model of corporate management. Universal nature of business education standards as well as standards in production and servicing became the key precondition for active horizontal integration in the American tourism sector. Throughout the whole second half of the 20th century the number of related diversifications was prevailing in this regard. Hotel chains were uniting with each other, similar trends were also observed at the markets of passenger air transportation and car rental. Vertical integration became common for American business relatively recently (Farmaki, 2017). By the time this type of integration became popular at the American continent, Europe already had a range of vertically integrated tourism holdings, the structure of which united hotel chain, airlines, tourist agencies' networks etc. At some point, American companies happened to be lagging behind since they did not want to abandon their expansion strategies and were still oriented primarily on creating the added value from the same tourist product.

Still, later on, American hotel chains have been managing dozens of world-famous brands, having representatives in nearly all countries of the world, while their airlines have been flying from any point A to any point B. At the same time, American companies were not rushing to finalize the process of transnationalization since the latter eventually meant their finite merger (Mikhailushkin and Shimko, 2015). They were forced to cooperate more only at the very end of the 1990s when competition with their European colleagues became quite intense. As it was already mentioned, tour operating and retail sector as such was of little interest for American companies for quite a while, mostly due to the absence of large tangible volumes in this sector (Khairiree and Ushakov, 2016). Therefore, American tourism business was concentrating on the production of own, standard but still competitive tourist services, later sold to huge numbers of consumers (via agents or directly, it was not that important for companies themselves). Such standardized services were mostly sold via universal tourist stock exchanges that were popular at the end of the 1990s. Roughly at the same time American TNCs realized they had to pay more attention to individual requests of clients who wanted to purchase the whole, readymade package of services. At the same time, a typical client also wanted all their individual requests to be taken into account. Finally, this typical client wanted to minimize the spending of all resources (including not only financial ones but also time and emotional resources) in the course of selecting and purchasing a tourist product.

On the one hand, all these trends were beneficial for American conglomerates, the structure and the system of which were ready to comply with the standardized requests of their current and potential clients. Hotel chains, airlines, car rentals, tour agenc ies - all of them were ready to provide services to their American clients in strict compliance with quality standards "just like at home". American hotel and transportations conglomerates had well-tuned systems for interaction with intermediaries and using them, were actively developing the retail segment of their service sales. However, during that period of time American tourism business was not able to produce such packages of tourist services that would be able to satisfy the averaged demand at the market. Moreover, even huge tour opera tors in the USA were operating under the shadow of global hotel chain and airlines. This situation caused a range of structural changes at the American tourism market at the very end of the 1990s. Large hospitality and transportation businesses started to pay their attention to a relatively new (for that time) phenomenon of e-commerce. Also, more of their attention was paid to small and even family tourist agencies. American TNCs started to launch their own tour operating departments, early activity of which was directed on satisfaction of tourist demand of the clients from their parent company. In such a way hotel chains have been forming specialized production structures which were formulating their tourist package offer on the basis of accommodation in their own hotels.

Airlines, in their turn, started to promote their additional services of hotel booking and car rental in the cities most visi ted by their passengers (Bandurin, 2019). Since this sort of tour operators were founded within the structures of transnational conglomerates, it would be logical to assume that American tour operating was functioning at the transnational level of management since its very early days. Traditional for American tourism conglomerates is inclusion of financial institutes (banks, investment funds etc.) into their structure. They guarantee corporate stability and serve as the most stable sources of financing for transnational business activity.

\section{Specific Features of European Tourism Business}

German conglomerates emerged at the end of the 19th century as vertically integrated groups. They were quickly expanding and developing in two directions at the same time: downward - from processing industries to mining and agriculture; and also, upward - to the markets of end products. The necessity of their rapid development was predetermined by the need for stronger control over spending and quality, and also control over demand. Also, these German conglomerates were performing an important function of social integration balancing between rather high corporate technical qualifications and average level of population education overall.

Most of German concerns were family businesses (Choo and Petrick, 2014). Banks started to play their important role in conglomerates of German model relatively late - only after the World War II. European model of corporate financing can be 
characterized by high dependence of companies from banks' capital and very high level of indebtedness in relation to owned capital. Under this scenario banks do not function as competitive credit institutions, instead, they try their best to lure their corporate clients into the system of complex and long-term relations. Capital markets are overall less developed.

As compared to market-oriented American conglomerates, German companies are much less transparent, they choose to disclose their corporate information rather selectively. In tourism conglomerates of Europe (Germany in particular) control is fully in hands of the so-called insiders (Lin et al., 2019) who are the persons with full access, due to their position, to internal information on corporate performance and company's development prospects. In the US insider is any owner of at least $10 \%$ of shares, and also any of the directors or other top managers. In Europe or Japan about $70 \%$ or more of all shares usually belong to financial groups or other affiliated with a corporation structure. Thus, control over all insider activity is organized by the leading bank. This bank is not only the major shareholder but also the core creditor of a conglomerate. Various corporate structures, shareholder agreements, discriminatory voting and other semilegal practices are widely applied to decrease the participation rate of minor shareholders.

Sometimes the organizational structures of European tourism TNCs (especially those of pyramid type) allow investors with the dominating role in the parent company fully control the branch, even if they have a minor share in it. Another widely spread way of redistributing control is issuing shares of several types so that to make sure that all insiders own shares with the special voting right (Chen et al., 2016). If in the USA the key owners are mostly institutional investors, in Germany, as a rule, these would be other corporations. Another distinctive feature of the German model is high concentration of shareholder capital. For example, back in 2008, 27 out of top-40 largest German conglomerates had at least one owner with more than $10 \%$ of all shares. And in the absolute majority of all German conglomerates three owners together cover more than 50\% of all corporate shares (Van et al., 2017).

For this very reason owners under the German model, unlike their counterparts under the American one, have all the capacities and personal interest as well to use the owner right and participate directly in control over corporate management. Specificity of the German model has initially predetermined both strategic priorities and tactical decisions of European tourism companies. As it was already mentioned above, the majority of these companies were created in the post-war era already and predominantly within large industrial conglomerates or retail networks. For example, the well-known globally German conglomerate TUI originates from a steel concern, while famous REWE group was founded by the same-name retail network which, at some point, was the largest in Europe and quite influential at the world markets as well. One more specific feature of European TNCs operating in tourism is the fact that from the very beginning most of them were concentrated on product development. They did not practice down-top strategy and they never started from hotel chains or airlines. For quite a while European hotels and transportation companies were developing independently from the tourism sector. And when first tour operators emerged at the market (German and Spanish ones), they were more like usual big clients with onetime orders, and they were never owners or founders of travel agencies or hotels etc.

In our view, this is the first of principal differences between German and American large businesses operating in the tourism sector. European companies, from the very beginning, were oriented on the formation of standardized tourist product, they were always looking for their own, specific niche at a market and they were also ready to invest heavily in the development and strengthening of their own tourism brands (Mikhailushkin and Shimko, 2015). Quite soon many of these brands became famous not only in the Continental Europe but also in the UK, US and Canada. Besides that, German tourism conglomerates were developing in the context of intensive non-related diversification carried out by their parent companies, while American tourism business as such rests on the related diversification (Rogerson and Rogerson, 2020). The very history of European tourism TNCs' development is the history of vertically integrated holdings. Tourism conglomerates were expanding upwards and downwards orienting on the value chain of their key tourist product and investing actively in hotels, transport development, agents' network etc. This European strategy of growth, on the one hand, guaranteed the growth of competitiveness at the tourism market thanks to lower prime cost of a tourist product and extra guarantees of its quality (since in this case several intermediaries were excluded from the chain of tourist package formation). On the other hand, thi s strategy also means rather strict positioning at the market since initially low financial capacities of companies did now allow for intensive, multidirectional investment (for example, in several hotel chains at the same time). And this led to lower assortment of tourist product offers which, in its turn, meant narrow specialization at the market.

Once European tourism companies became solid at their market, increased their investment rating, confirmed their reputation with their corporate bank - they moved to the second stage in their development (in chronological terms, this was late 1980s - early 1990s, at least, for most of these companies). At this second stage European tourism conglomerates started concentrating resources and ef forts exclusively on the formation of their tourist product (Choo and Petrick, 2014). The key strategy at that time was getting rid of unprofitable assets or those of secondary importance for the core business. Once they got rid of this "dead load", tourism co rporation got another stimulus for competitiveness growth since they also got additional assets for further expansion.

Therefore, at the turn of the century, TNCs broke nearly all connections with parent companies since tourism became basically the only type of activity. This is yet another difference of the European model from the American one. The latter used to stay within the structural groups of their parent companies since these parent companies were often too famous and too large to abandon them (take, for example, one of the largest American tour operators - American Express - it is still just a structural unit within the largest in the world financial empire). Another distinctive feature of European tourism business is its marketing strategy which is normally based on the umbrella brand of a parent tour operator. Let's take TUI again: this conglomerate owns hotels under the same name, tourist agencies with the same name, excursion buros, transportation companies and so on. This wide spread of the brand name increases the loyalty of consumers dramatically, despite all possible accusations in the oligopoly at the market. European tourism TNCs focusing on the development of own brands inevitably led to the upswing of intercorporate deals and projects in the course of which corporations join their financial and marketing capacities. Intercorporate communications and cooperation in Europe (in the form of traditional partnership and also as mutual capital investments) is much more developed than in the USA. Tourism corporations of the Old World are traditionally more open for joint projects' initiatives and are always ready to enter together new tourist markets or explore together new destinations, implementing joint investment projects, etc. The second important trend at the contemporary European market of tourist services is expansion at foreign markets. European expa nsion has a range of serious differences from the American one. If US tourism companies are expanding mostly in the transportation and hospitality sectors - European companies are focused mostly on tour operating and tour agencies, that is, on those segments in which they, by default, have significant competitive advantages over their American counterparts.

Expansion of European tour operators is usually based on one and the same scheme. First, the company does thorough research of the market of interests, determining the most commercially successful tour operator at it. Then it buys this operator out. The purchased enterprise keeps its brand (at least for some time), however, at the same time it gradually starts popularizing the brand of the European company. All further moves are quite easy and quick. The purchased company starts quite aggressive dumping, thus forcing nearly all national tour 
operators become its agents (they simply do not have any alternative under such circumstances). After some time, European corporation would offer franchising schemes to all the survivors at the market, thus increasing own presence at this market to its very maximum. Under this scheme, expansion was carried out in Eastern Europe, Nordic countries and also some of the post-Soviet countries. Resistance to expansion at all these markets was close to zero since competitive fight again such a strong global competitor would have been possible only in one case - if all national tour operators would have united their efforts and assets. And this scenario was impossible both for Eastern Europe and for the CIS, their markets were too "raw" for that (Hall, 2014). Therefore, the key specific feature of European expansion in the tourism sector is monopolization of all relations with consumers directly. This also means maximum presence at the consumer markets.

For this very reason today European tourism companies pay much attention to their orientation on client. European companies also became the initiators of global tourism stock exchanges which provide consumers with the opportunity to form their tourist product independently (Khairiree and Ushakov, 2016). European companies have also invested heavily in marketing and personal sales, building the whole monobrand empires of agent networks in various countries worldwide. Unlike it is in the USA, hotel chains in European countries do not enjoy that much popularity, thus, they are unable to play a meaningful role in transnationalization of European tourism business. Until now, more than $80 \%$ of all European hotels are independent business units, not members of some chains, neither national, nor global ones. The largest European hotel chains are Accor (France) and Sol Meglia (Spain), they can be actually called global corporations, however, as compared to their American counterparts, their geographical coverage and overall size are much poorer.

Some of European countries also have national hotel chains, for example, IberHotel in Spain or Sokos in Finland. However, in the context of the world tourism market the role of counterbalance to American aggressive expansion is really secondary. However, they usually have another competitive advantage which may be of interest to some tourists: their interior design, services and meals traditionally represent local specificity. As compared to the USA, in Europe the process of tour operators' formation on the basis of airlines has just started. As it was already mentioned above, on the American continent tour operating started from within hotel chains and airlines (that is, being part of related diversification). However, since in Europe world hotel chains were not that strong, tour operating was developing mostly in the context of non-related diversification of various other parent companies. Today some of European airlines become the initiators of such related diversification and create their own tour operating companies, however, the market share on the continent is really insignificant.

Extra attention to client orientation expressed by European large tourism companies contributes to more positive image, raising the brand value and boosting client loyalty, however, it also leads to the necessity to invest much more actively in intangible assets. If American companies are more interested in quick positive reaction of the stock market and thus prefer deals with significant material backing (mostly real estate, such as hotel or restaurants) - European ones demonstrate much more interest in acquiring foreign tour operators or agent networks, the core assets of which are popular brands and loyal clientele. At first glance it seems that restructuring of corporate assets in favor of intangible element is a logical trend for today's global business environment (Duerden et al., 2018). On the other hand, dominance of intangible assets in the structure of corporate ownership increases the vulnerability to market fluctuations. The last but not the least specific feature of tourism business functioning in Europe is the strongly decisive role of trade unions and of the state.

Professional unions of hospitality and tourism workers as well as of those working in catering and for transportation companies together form a powerful instrument, quite capable to correct and redirect the development of corporate management in the tourism sector. Members of such professional units are actively using their rights to push own agenda in relations with top management of tou rist TNCs (Choo and Petrick, 2014). This helps maintain the internal balance of the insider model of corporate business used in the majority of European countries till today. If in the US state authorities have two roles only at the tourism market - the market relations' regulator and the conductor of anti-monopoly policy, the European model of tourism sector management assumes immediate presence of national governments at the tourist market. Moreover, national authorities are not just present - they are active participant of this market. National states at the European market of tourist services are directly involved in the following activities: anti-monopoly regulation; labor rights' protection; international promotion of national tourist products.

\section{Transnationalization of Islamic Tourism}

One of the core forms of corporate management which has its rightful place in the system of world tourism production is the socalled Islamic model of transnational corporation. Its features are very different from classical Western models of corporate management; however, they have never provoked any resistance in the world business community (Khairiree and Ushakov, 2016). Today Islamic states are already far from being some sort of secondary participants at the world market of tourist services. They are fully engaged in the processes of tourist flows' generation as well as in the processes of welcoming foreign travellers at home, at their famous resorts and vibrant city centers. Some of the Islamic states are promising markets in terms of tourist services' sales due to their const antly growing welfare level, their numerous populations and often quite relaxed business conditions which are encouraging many overseas businesses, including those directly related to the tourism sector. Good examples in this regard are Kuwait City (capital of the same-name country), Dubai in the United Arab Emirates, Doha in Qatar, Manama in Bahrain or Aqaba in Jordan - these are largest, global-scale projects on creation of free economic zones and also active financial centers. At the same time, such states as Malaysia, Saudi Arabia, Oman and Turkey are quite interesting markets due to huge population numbers and enormous market capacities. Additionally, the potential of Islamic world to generate tourist flows is partially hidden since many European countries as well as USA, China, India and so me of postSoviet countries have significant share of Muslim population too. Separately we need to mention the prospects of Islamic states to become the "next big thing" in international tourism anytime soon. They have all necessary preconditions for that: rich histo ry, original and unusual (for representatives of other cultures and religions) culture, high concentration of religious sites on their territory, relatively soft visa and customs regime and also well-developed infrastructure (Van et al., 2017). Many already implemented (or those in the process of implementation) tourism projects leave similar Western projects far behind - both in terms of size and in terms of costs. Such projects have already become popular tourist destinations for many Western tourists: Iranian island Kish in the Persian Gulf, Dubai in the Emirates, Marsa Alam of Egypt, Port El Kantaoui in Tunisia, both Mediterranean and Aegean costs in Turkey as well as Turkish ski resorts.

All these resorts are yet another proof that governments in Islamic countries are prioritizing tourism development and also have all the capacities to attract foreign tourists and guarantee they will be provided with products and services of the highest quality. Since the market of international tourism is still developing quite dynamically, it is quite logical that large and specialized companies are still emerging in the Islamic world, and many of them are in the process of transnationalization. The usual rules of Islamic company's operation are fully applicable to tourist services' production as well (Chen et al., 2016). Tourism, actually, is not only allowed by Islam but is considered to be a top-priority activity due to its positive influence on welfare and society overall. Travelling as such is interpreted as having spiritual value, consequently, all spending on travelling and all related activities (including organization of tourism travel and welcoming foreign tourists at home) are encouraged, generally speaking, even though there is also a range of bans and limitations 
stemming from the Islamic religious tradition. As applied to corporate management and policies of tourism companies, the following limitations may have a certain influence on corporate rules and performance (Albayrak and Caber, 2018):

- The ban on any type of activities, directly or indirectly related to production and sale of alcohol. Participation of an Islamic corporation in these types of activity, even abroad and/or when servicing tourists from other religious groups, is unacceptable. As applied to business, this fact often predetermines the choice of objects for foreign investment.

- Prioritizing other Islamic states or countries with significant shares of Muslim population in the external strategies of Islamic tourism companies. This prioritizing concerns both investment projects as well as sales strategies' development, expansion on certain markets etc. Numbers say it all: over 70\% of all foreign investments in the Islamic world are directed into other Islamic countries (Zhdanov, 2003).

However, this limitation is becoming more and more formal, actually. Internal demand in the Islamic world has its limits, mostly because many Islamic countries are still developing, thus paying capacity of their population is not that high. This forces leader of the Islamic tourism to take extra efforts so that to attract tourists from other, richer states of both Old and New Worlds. Saudi Arabia is quite an interesting example in this regard. For decades, this country was notoriously famous due to numerous religious limitations. It used to deny entry to the country for non-Muslims, then this ban was lifted, however, visas were still hard to get. However, since the spring of 2016 the new generation of rulers in the country made the decision to ease the procedures for tourist visas so that to attract European tourists to their Red Sea resorts.

Apart from the limitations mentioned above, both internal and external activities of Islamic tourism companies are under the constant influence of the Islamic financial system and Shariah laws and principles of doing business. In the Islamic banking system, the leading role in capital accumulation belongs to the state. Bank investments in the private sector are nearly impossible. This is very different from the traditional (for Europe) system of financial interactions at the tourism market since in the Islamic world only state tourism companies (and of course, they are in the absolute majority at the market) have the ability to attract bank assets for further investment at home and abroad. Private tourism business is thus forced either to accumulate own funds for further investments in development (borrowing from Western banks is also strictly prohibited), or cooperate with Islamic banks and other financial institutions according to the Shariah laws and rules. This cooperation of Islamic tourism companies with Islamic banks is based on the following concepts: mudarabah - participation in profits, musharakah - participation as partnership, murabahah - contract for further resale, ijara - leasing contract, and istisna (compensation deal). Of course, these are only a few options available for financial operations at the Islamic tourism market. In some cases, businessmen camouflage non-Islamic financial practices interpreting them in a way so that they look as Shariah-approved. Taxation of financial operations is based on the principle of zakat - obligatory expropriation of income in favor of the poor (in real business practice this usually means fixed sums, in the amount of about 2.5-5\%).

Since Islamic economy bans interest rate, neither private companies, nor Islamic banks are allowed to sell or buy money at the market of credit relations. In this situation, companies and banks with sufficient volumes of financial assets thus become comprehensive trade \& investment intermediary institutes at the markets of commodities and services. Acting as intermediary market agents, they are able to promote the capital outflow from less commercially efficient segments to more efficient ones. Capital, in this case, is attracted directly into the charter funds of the most successful companies of the sector. N. Zhdanov (2003) is of the opinion that equity finance as a method of assets mobilization without direct participation in capital is actually the basis of the Islamic financial system. Others state that equity finance is the future of corporate finance as such. At the same time, operations related to equity finance are not able to cover all the growing necessities of the financial market, especially when it comes to credit funds' availability. Also, there is a problem of limited access to charter capital of companies that are not public (that is, of those companies the share of which are not traded at stock exchange).

Corporate Boards and banks track thoroughly all their financial and investment flows so that to make sure that none of them is directly or indirectly financing activities of the companies engaged (or somehow related) to alcohol production, insurance or pornography. This means that every potential object of investment is passing through the multilevel system of monitoring, with several serious filters. The first filter sorts out those companies that are producing products and/or get incomes against the Shariah laws. Then companies with high credit indebtedness are sorted out too and also those that are getting income from using interest rates. It may seem strange first but these and other peculiarities of the Islamic financial system became the key causes for quick transnationalization of Islamic tourism companies, mostly due to the fact that Islamic schemes of financing, apart from mutual commercial benefit for the both sides involved, also mean the alignment of production processes belonging to the interacting market subjects, even if they are located in different countries.

For example, the application of mudarabah requires certain control over the commercial activities of the trusted subject by the principal grantor since the latter is financially interested in success of their new mutual business. If in the European banking system the creditor sets the interest rate and "let the borrower free" for a certain period of time, being interested only in timely return of the sum (credit + interest rate), thus having no connection with the borrower themselves - within the Islamic financial system the situation is exactly the opposite (Brida et al., 2016). The creditor starts performing some sort of a patronizing function in relation to business of a borrower, supporting their new initiatives and ongoing projects, thus forming a solid platform for further consolidation of parent and filial businesses. Similar positive consequences in terms of ongoing transnationalization may also have murabaha and istisna. Musharakah initially requires close partner relations between the sides of an investment process. Consequently, if these Shariah-approved schemes of financing are used wisely and efficiently - there will be an additional reason for further merger of production processes of two (or more) initially independent types of businesses.

A tourism company, having all necessary resources for investments and operating at Islamic financial market, in many cases would be interested in opportunities for further cooperation in the same field (tourism) since in it, managers of this company would have enough knowledge and skills to make a grounded decision concerning any of the offered projects. Considering also the ban on insurance activities and consequently, absence of habitual for the West instruments to reduce the investment risk, it would also be logical to assume that transnationalization of the Islamic tourism capital is carried out within the framework of related diversification, when parent TNCs invest in some foreign branches, directly related to their core activity - tourism. The most frequent and the largest in volume transnational deals in the Arab world usually imply investments carried out by tourist or hotel chains in similar business somewhere abroad (for example, buying out several hotels and acquiring a national tour operator). They also invest in transportation and construction sectors since the latter have direct impact on the state of tourism development at the regional level.

Same as in Europe, tourism businesses of the Islamic world first demonstrated certain lagging behind in their transnationalization rates, as compared to other economic sectors (especially construction, mining, transportation, textiles, wholesale trade etc.). The major cause for this lagging behind was late development of international tourism in Islamic regions in general. First Muslim resorts (those outside former European colonies) appeared on the world map of tourism in the 1980s only, and during the first decade of their existence they were not that much profitable. Moreover, national tourism business of certain Islamic countries (Egypt, Tunisia or Lebanon) was a constant victim of political instability and frequent terror acts. We can even state that in all three mentioned above countries tourism is still at the stage of financial assets accumulation so that to invest later in some project abroad. Also, there might be so that the countries have already lost their opportunity to develop transnational tourism business of their own due to already well-established leadership of Western corporations on their territories. 
Due to this lagging behind it also became logical that some of the transnational tourism companies in the Arab world emerged from inside the already existing other corporations, only indirectly related to tourism business. Most successful in transnationalization have been construction and transportation companies, and also some of the hotel chains in the Emirates. Thus, it is quite predictable that in the last 5-7 years all these businesses have come to the idea of creating their own tourism enterprises or tour agents' networks. For example, the worldfamous holding Emirates (one of the structural units of which is the most profitable and the most dynamically developing airline in the world - also Emirates) has been an active participant of the state holding Dubai Tour Development Group since 2001. This state holding is carrying out a range of projects aimed at complex development of the tourism infrastructure in the United Arab Emirates. And it is also actively investing in the tourism sectors of Saudi Arabia, Jordan, Egypt, Iran and even some of European countries. Finally, we need to state that the Shariah-approved types of commercial activities, including those at the financial market, also stimulate the deals in which both sides can be branches of the same corporation, for example, branches located in two different Islamic countries. Such operations tend to reduce all business risks to the very minimum since all investment activity is carried out under murabaha and/or musharakah. This, in turn, optimizes all business processes and all joint activities of corporate structures. Therefore, all Shariah-approved financial operations become the basis for intracorporate relations of Islamic TNCs, especially when it comes to communication between different structural units. Therefore, we can make a conclusion that the core contents of corporate management at the Islamic tourism market has many differences from the traditional Western corporate management. Moreover, Islamic corporations are, to some extent, in a more beneficial situation as compared with their American or European counterparts thanks to the specificity of their organizational structure, methods and principles of corporate management.

For example, when Western companies come to the idea of partnership and merging their value chains - they usually end up with a flat network-like structure with low level of centralization. Thus, they have to search for new forms of interaction between their headquarters and other structural units. Their structures transform under the influence of market factors, sometimes such networks lose their best players simply because the latter do not want to change and restructure. At the same time, Islamic corporations by default are all ruled by the same religious principles, and Shariah for them is one and only legal basis. Moreover, as it was already mentioned above, all Shariah-approved forms of financial activities and business partnership as such promote business enlargement and transnationalization in a much stronger way than Western individualism and liberal values are able to. Regarding international tourism markets and transnationalization in the Islamic world we need to mention several peculiarities which mostly stem from the Shariah-based limitations imposed on businesses.

Since the scale of banned activities is quite large (everything related to alcohol, pork, insurance and also some of the stock exchange operations), most of financial operations in international Islamic tourism are carried out as direct investments. When the act of investment is direct, the Board of an Islamic TNC can rest assured about the "purity" of an investment object, moreover, in this case there is no interest rate involved which is also banned by the Shariah. When top management of an Islamic TNC, for some reason, needs to avoid the Shariah imposed restrictions, the owners (or the most influential shareholders) tend to entrust the tactical level of operations to Western managers. This is especially relevant for the hotel chains that do not have a strong brand, neither their own trademark (apart from the famous Jumeirah Hotels and Resorts). If they don't have strong brands of their own - they may enjoy the benefits from being managed by world famous Western companies. Under this scheme of foreign investment, the larger share of income is concentrated in the hands of a parent Islamic corporation while the managing Western company gets either some fixed amount, or a percentage from profit.

In this case the Islamic corporation intentionally limits its recognizability at the local market and also sacrifices part of its income flow; however, it also solves several problems related to servicing international clients (including sales of alcohol drinks, cooking meals from pork, providing rooms with cable TV channels, some of which may contain pornography). Thus, a certain two-level hotel system is being formed. The immediate owners of the hotels are Islamic TNCs, they are also the key investors in their development and infrastructure, they share all investment risks etc. However, direct management, both strategic and operational, becomes the responsibility of Western companies and their managers. Here, the interests of Western and Islamic tourism corporations are not intercepting - they achieve their own aims in parallel. Western companies tend to strengthen their presence at consumer markets worldwide, they concentrate on the marketing aspect and services' provision, while Islamic corporations tend to concentrate on their tangible assets, real estate and infrastructure around, thus, they are more engaged in construction of new hotels and/or acquiring the already functioning ones (Kolosinska et al., 2018). This state of affairs is typical not only for the hospitality subsector, actually. In many fields of production activities or in trade Western companies tend to make use of their technological advantages, marketing skills and more qualified labor overall (especially when it comes to management).

In such a way they provide some sort of "envelope" around their capital- and labor-intensive productions. Noteworthy, availability of such an "envelope" usually serves as the guarantee that the produced commodity would reach Western consumer markets, having global competitive advantages of their own. In the spheres of tour operating and retail trade of tourist products Islamic tourism corporations did not manage to achieve significant results, as compared to Western TNCs. This is related, first of all, to low internal demand for tourist product and also to obvious technological lagging behind (which is especially visible when it comes to marketing and PR, and also strategic management in the service sector). The major consumers of their tourist product at the global markets come from developed democratic states of the West, while their own internal markets of tourist products are unreachable for Islamic corporations, at least as of today.

On the other hand, this does not mean that Arab tourism companies would lose interest in the West, neither this lessens their ambitions to conquer Western markets. For the implementation of this longer-term strategy the governments of some of the Islamic states have already created a solid platform - their strong internal markets protected from Western influence. This is quite promising for these states since their internal tourism potential has only recently started growing, and today its growth rate is already quite high. At this, these internal markets create all necessary preconditions for raising their own, national champions in the tourism sector so that later to "insert" them onto the Western consumer markets. Of course, Islamic tourism corporations entering Western market is a very distant future scenario, and for the many this scenario may seem unrealistic as such. However, we need to keep in mind that the share of Muslim population in many European countries as well as in the USA, China, Japan, Russia etc. is only growing. And these growing population numbers will soon be able to become one huge platform of loyal clients, when the right time comes to Islamic tourism expansion to the Western markets.

Islamic corporations themselves are very well aware of what is their most perspective product - the Islamic tourist product. Previously, Islamic tourism meant only hajj and umrah (two types of pilgrim journey to Mecca), however, today Islamic tourism corporations are ready to offer a much wider choice of Islamic travels: leisure in Islamic traditions, Islamic resorts, spiritual tours, education tourism (Cairo, Istanbul, Tehran etc.). The growing variety of tourist products offered by Islamic companies is gradually forming a new unique niche at the international tourism market, while the growing numbers of Muslim population worldwide guarantees Islamic tourism companies that very soon, will find their own place in global tourism. As the final note on Islamic tourism business we need to mention the following feature the role of the state in Islamic business in general. Many other specific features of Islamic TNCs are deeply rooted in it.

The role of state authorities at the tourism markets of Islamic states is predetermined, in the first place, by the level of tourism production development and also by financial self-sufficiency of tourism companies. This role may range: from the function of control over the quality 
of tourist services provided (most frequently this means development of national standards in tourism servicing provision) to guaranteeing security to foreign tourists coming to a country (in some countries this even means the establishment of the so-called tourist police). The state may also regulate prices for tourist services, accommodation, passenger transportation etc.

\section{CONCLUSIONS}

The American model of corporate management, the emergence of which has been provoked primarily by the inflow of migrants to the country and also its interactive economic policy of expansion, is based on the individual entrepreneurial initiative, equation of technological progress with economic success and the system approach to management. Functioning of the US corporate sector is under the constant influence of financial institutions and their lending funds. The priority role in management belongs not to owners (who are often a combination of many minor shareholders) but to professional top managers. In relation to the American model separately we need to mention the regulating role of the state. Rigid anti-monopoly laws guarantee wider authorities for state bodies in regulation of corporate activities. At the same time, there is hardly any state support provided for the tourism sector. The American state has been not involved in promotion of national tourist product; thus, this function of promotion has been fully transferred onto independent organizations, or corporations had to join forces for campaigning.

Unlike their American counterparts, huge production-distribution systems in Europe from the very beginning were forming in very close connection with financial institutions, often with the priority role initially given to the latter. Secondly, European model was being formed and developed in the structure of large businesses not directly related to tourism (industrial enterprises, retail chains, for example). Domination of common interests over private ones in German corporations means that all short-term interests of shareholders and investors become of secondary importance. This stimulates vertical integration in this sector, including the one aimed at the consumer. All European countries where tourism is (or potentially can be) one of the leading sectors within national economy, have wellfunctioning national tourism organizations, the key goal of which is promoting these countries at the world tourism market. Eexternal marketing for Germany as a country attractive for international tourists is organized and carried out by the German Center for Tourism, organization founded by German federal government.

Islamic model of corporate management is based, in the first place, on the bans on interest rates and mandatory social tax. Absence of interest rate and also prohibition of commercial projects' financing by financial institutions together have stimulated the e mergence of rather original forms of cooperation between service companies with each other and also with banks. This form of cooperation is based not on strict division of commercial results but rather on the shared responsibility of partners for common implementation of projects. And this becomes the original Islamic platform for transnationalization. In the Islamic world the state and large tourism companies are more like partners rather than parties in the process of some sort of vertical interaction. The state not only controls but consolidates larger projects, including international ones, making sure all related financial transactions do not contradict Shariah laws. In their turn, corporations are responsible for creating comfortable conditions for the development of the related small and mid-sized businesses, including those directly affiliated in the structure of TNCs in tourism.

\section{REFERENCES}

Albayrak, T., \& Caber, M. (2018). Examining the relationship between tourist motivation and satisfaction by two competing methods. Tourism Management, 69, 201-213. https://doi.org/10.1016/j.tourman.2018.06.015

Al-Zahawai, M.I., Bilal, A.T., \& Al-Daloy, S.E. (2019). Activating and managing camping tourism and its role in increasing tourist's expenditure. Journal of University of Human Development, 5(1), 44-60. https://doi.org/10.21928/juhd.v5n1y2019.pp44-60

Bandurin, A. (2019). Corporative activity, Bukvitsa, Moscow.

Bigné, E., \& Decrop, A. (2018). Paradoxes of postmodern tourists and innovation in tourism marketing. The Future of Tourism: Innovation and Sustainability, 3, 131-154. https://doi.org/10.1007/978-3-319-89941-1_7

Brida, J.G., Cortes-Jimenez, I., \& Pulina, M. (2016). Has the tourism-led growth hypothesis been validated? Current Issues in Tourism, 19(5), 394-430. https://doi.org/10.1080/13683500.2013.868414

Chen, J.S., Wang, W., \& Prebensen, N.K. (2016). Travel companions and activity preferences of nature-based tourists. Tourism Review, 71(1), 45-56. https://doi.org/10.1108/TR-06-2015-0024

Chingarande, A., \& Saayman, A. (2018). Critical success factors for tourism-led growth. International Journal of Tourism Research, 20(6), 800-818. https://doi.org/10.1002/jtr.2233

Choo, H., \& Petrick, J.F. (2014). Social interactions and intentions to revisit for agritourism service encounters. Tourism Management, 40, 372-381. https://doi.org/10.1016/j.tourman.2013.07.011

Comerio, N., \& Strozzi, F. (2019). Tourism and its economic impact: A literature review using bibliometric tools. Tourism Economics, 25(1), 109-131. https://doi.org/10.1177/1354816618793762

Duerden, M.D., Lundberg, N.R., Ward, P., Taniguchi, S.T., Hill, B., Widmer, M.A., \& Zabriskie, R. (2018). From ordinary to extraordinary: A framework of experience types. Journal of Leisure Research, 49(3-5), 196-216. https://doi.org/10.1080/00222216.2018.1528779

Farmaki, A. (2017). The tourism and peace nexus. Tourism Management, 59, 528-540. https://doi.org/10.1016/j.tourman.2016.09.012

Hall, C.M. (2014). Tourism and social marketing. Tourism and Social Marketing, 1-295. https://doi.org/10.4324/9780203854259

Khairiree, M.D., \& Ushakov, D. (2016). Sufficiency economy as an alter-globalist development concept: Topicality factors and conditions needed for introduction. The EURASEANs, 1, 7-20.

Kolosinska, M., Petrashchak, O., Kolosinskyi, I., \& Katana, A. (2018). Tourism sector in transition economy on example of Ukraine: Determinants of competitiveness. Geojournal of Tourism and Geosites, 21(2), 239-252. https://doi.org/10.30892/gtg.21119-284

Lin, H., Zhang, M., Gursoy, D., \& Fu, X. (2019). Impact of tourist-to-tourist interaction on tourism experience: The mediating role of cohesion and intimacy. Annals of Tourism Research, 76, 153-167. https://doi.org/10.1016/j.annals.2019.03.009

Mikhailushkin, A., \& Shimko, P. (2015). Economy of transnational company, High School, Moscow.

Rogerson, C.M., \& Rogerson, J.M. (2020). Camping tourism: A review of recent international scholarship. Geojournal of Tourism and Geosites, 28(1), 349359. https://doi.org/10.30892/gtg.28127-474

Ushakov, D. (2006). National tourism industry: Problems of development, Granitsa, Moscow.

Van, H.T., Huu, A.T., \& Ushakov, D. (2017). Liberal reforms \& economic growth: Current issues and interrelations. Journal of International Studies, 10(4), 109-118. https://doi.org/10.14254/2071-8330.2017/10-4/8

Zhdanov, N. (2003). Islamic model of the world order, International Relationships, Moscow. 